\title{
TILL TEXTURE IN DRUMLINS
}

\author{
By P. F. Karrow \\ (Department of Earth Sciences, University of Waterloo, Waterloo, Ontario $\mathrm{N}_{2} \mathrm{~L}_{3} \mathrm{Gr}$, Canada)
}

Asstract. Drumlin till has often been described as clay-rich. Drumlins in Ontario are composed of sandy till. Additional examples from north-eastern North America show that sandy till is common in
drumlins.

It is suggested that the widely accepted association between drumlins and clay till was fostered by the use of such terms as "boulder clay" and "glacial clay". Also, because till in drumlins may be finer than other glacial materials in such areas as the Appalachian region, a loose and exaggerated description of such material as being clay-rich arose. More careful description of drumlin till is advocated. It is suggested that grain-size distribution of till may have had a role in drumlin formation.

RÉsumé. Texture des dépôts dans les drumlins. On a souvent décrit les dépôts dans les drumlins comme riches en argile. Les drumlins dans l'Ontario sont composés de dépôts sablonneux. Des exemples supplémentaires provenant du Nord-Est de l'Amérique du Nord montrent que ces dépôts sablonneux sont communs dans les
drumlins.

On pense que l'association communément admise entre les drumlins et les dépôts argileux a été entretenue par l'utilisation d'expressions comme "argiles à blocaux" et "argiles glaciaires". Aussi, parce que les dépôts dans les drumlins peuvent être plus fins que d'autres matériaux glaciaires dans des régions comme les Appalaches, est née une description fautive et exagérée de ces matériaux comme étant riches en argile. On plaide pour une description plus soigneuse des dépôts des drumlins. On suggère que la distribution des tailles des grains dans les dépôts peut avoir joué un rôle dans la formation des drumlins.

Zusammenfassung. Schuttextur in Drumlins. Drumlinschutt wurde oft als tonreich beschrieben. Drumlins in Ontario bestehen aus sandigem Schutt. Weitere Beispiele aus dem Nordosten Nordamerikas zeigen, dass sandiger Schutt in Drumlins sehr häufig auftritt.

Es wird vermutet, dass die oft angenommene Zusammengehörigkeit von Drumlins und Tonschutt durch den Gebrauch von Ausdrücken wie "Geschiebemergel" und "glazialer Ton" gefördert wurde. Des weiteren ergab sich eine ungenaue und übertriebene Beschreibung des Drumlinschuttes als tonreich, weil der Schutt von Drumlins in Gebieten wie den Appalachen feiner sein kann als anderes glaziales Material. Es wird deshalb eine sorgfältige Beschreibung des Drumlinschuttes angeregt. Bei der Drumlinbildung könnte die Verteilung der Korngrössen im Schutt eine Rolle gespielt haben.

THE very extensive literature on the nature and origin of drumlins has been recently reviewed by Menzies (1979[b]) and supplemented by a further paper (Menzies, 1979[a]).

Of the many factors that have been considered possibly significant in the origin of drumlins, till texture has been given little emphasis. Many publications simply refer to till, with no further description of the nature of the till; some say drumlins are formed of clay-rich till, some say they may form of all types of till textures, and a few suggest drumlins are formed mainly of coarse or sandy till.

\section{SOME PUBLISHED STATEMENTS}

Because of the volume of literature, it is not practical to refer to all published statements but a few general ones, mostly found in textbooks, have been selected as representative.

Flint $\left(\left[{ }^{1}{ }_{1} 947\right]\right.$, p. $\left.{ }^{1}{ }^{23}\right)$ said "The majority of drumlins are composed of clay-rich till similar to the till in areas between the drumlins and packed so hard that it is extremely tough. Some, however, consist of sandy till. ... Most drumlins, whether consisting of drift or of rock, occur in districts where the bedrocks are rich in clay or in clay-forming minerals." Later, on p. 125, he said "... especially if the drift is rich in clay, drumlins will tend to form by progressive accretion". In his second edition, Flint ([ $\left.\left.{ }^{\mathrm{c}}{ }^{1957}\right]\right)$ did not describe the texture of drumlin till. In his third edition ([ $\left.{ }^{\mathrm{c}}{ }_{1971}\right]$, p. 102) he reverted to his earlier position, saying "Drumlins whose composition is known, at least in part, consist predominantly of clay-rich till, packed closely so that it is distinctly tough. However, in a few drumlin fields the till is sandy."

Charlesworth (1957, Vol. I, p. 391), after making passing reference to drumlins in northern Saskatchewan and Manitoba as sandy, said "Drumlins generally consist of the local boulder-clay." Most of his discussion of drumlin composition deals with rock cores. 
Embleton and King (1968, p. 327) stated that "some drumlins consist of mainly sandy material, while others are made up mainly of clay. Some are formed of true boulder clay, consisting of a mixture of subangular and striated boulders set in a clayey matrix." Much of the remaining discussion of material is concerned with stone orientation.

Bloom ([ $\left.{ }^{c} 1978\right]$, p. $\left.39^{8}\right)$ said of drumlins "They occur in clusters, most frequently in areas of clayrich basal till".

Menzies (1979[a]) remarked that generally "the till found within drumlins is similar in most respects to the till in non-drumlin areas". It is not clear whether this refers to till in drumlins and between drumlins, or in drumlin fields and elsewhere. If the former, I agree, but if the latter, I disagree. He further says "the matrix of till is normally a fine-textured material". This statement is not a very clear definition of texture but I have to disagree with it.

\section{SoME EXAMPLES}

\section{Southern Ontario}

Several drumlin fields occur in southern Ontario (Figs I and 2) and, since much of this area has been mapped at least at a scale of $\mathrm{I}: 62 \mathrm{ooo}$, the nature of the tills in the drumlins has been described. Speaking generally, Chapman and Putnam (1951, p. 18) noted that drumlins were "formed only of loamy till .... . Neither heavy boulder clay nor sand tills are productive of drumlins in southern Ontario." They also illustrate size-distribution curves for I 2 drumlin till samples that clearly show the finer than $0.002 \mu \mathrm{m}$ fraction is less than $10 \%$ of the till matrix and that sand and gravel constitute more than $50 \%$ of the till.

In fact, there is a close correspondence between coarse-textured tills and drumlin fields in southern Ontario. Thus, the Peterborough, Guelph, Woodstock, and Teeswater drumlin fields are all formed of sandy till. However, it is not true that sandy tills are always drumlinized. One exception is the Stratford Till sheet (Karrow, 1974) in the central part of south-western Ontario, but this is generally a thin till which overlies finer till, and has a relatively limited distribution.

Further refinement of the relationship of drumlins to till texture is worth noting. The Halton Till (formerly Leaside Till at Toronto) has a fine-sand texture in the east which changes to silty north of

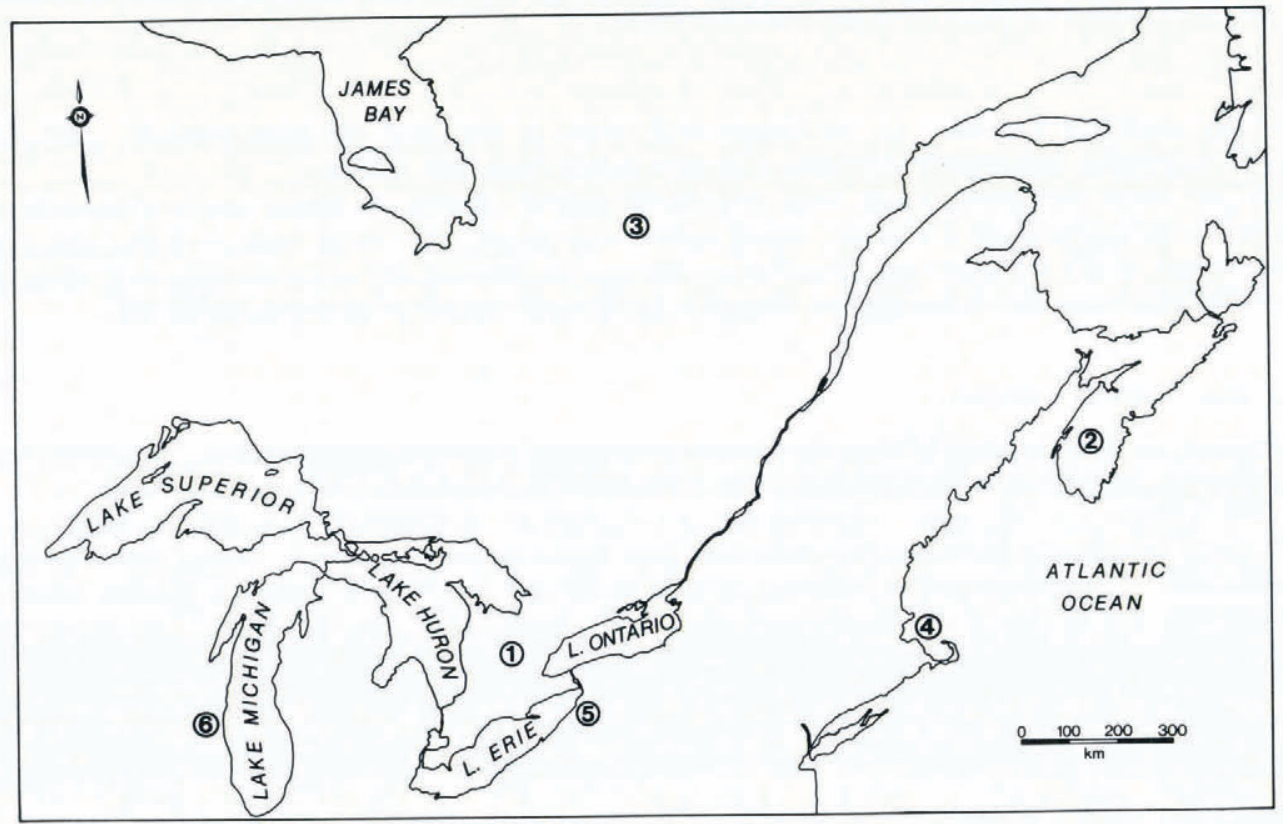

Fig. I. North-eastern North America showing drumlin localities referred to in the text. (I) Southern Ontario; (2) Nova Scotia; (3) Canadian Shield; (4) Boston; (5) New York; (6) Wisconsin. 


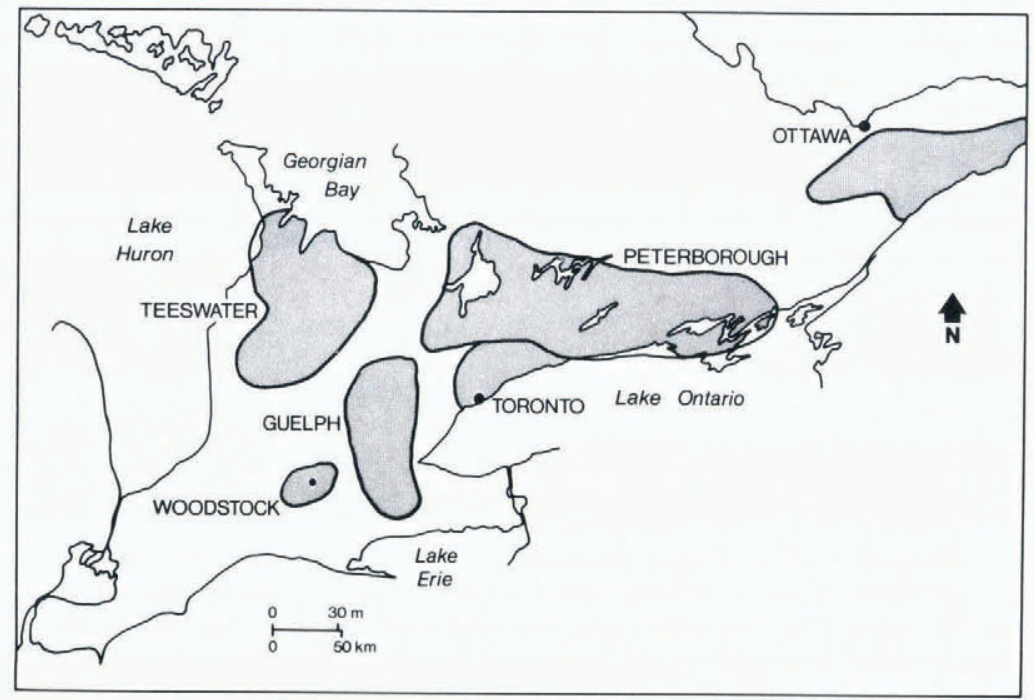

Fig. 2. Southern Ontario drumlin fields.

Toronto (Karrow, 1967, 1970). Coincident with this facies change, drumlins, which are prominent in eastern and northern Toronto, die out westward to be replaced by flutings (Watt, 1957; Karrow, 1963), which extend west to the Hamilton area through the area of silty Halton Till.

The Guelph drumlin field is composed of a sandy facies of Port Stanley Till and sandy Wentworth Till (Karrow, 1968, r974). Near the western edge of the Port Stanley Till, drumlins fade out into scattered faint flutings on a thin sheet of sandy till. No drumlins occur on the silty to clayey facies of Port Stanley Till farther south.

The Woodstock drumlin field (Cowan, r975) is composed of sandy Catfish Creek Till and a sandy facies of the younger Tavistock Till deposited during a later episode of overriding. Tavistock Till is usually a clayey silt till (Karrow, 1974) but near the outer limit of its extent near Woodstock it becomes sandy, apparently through the incorporation of older Catfish Creek Till. It is in this zone where the Woodstock drumlins occur. Faint flutings occur in the transition zone to sandy till and drumlins.

The Teeswater drumlins are formed of sandy Elma Till (Cowan, 1979). Near the outer limit of this till sheet, the till becomes very silty and the drumlins rapidly fade out with well-developed flutings in part of its extent where the till is fine-textured.

Drumlins south of Ottawa are also composed of sandy till with the matrix consisting of $50 \%$ sand (Sharpe, 1979).

In summary, drumlin till in southern Ontario is generally sandy. There are examples of single-till sheets, deposited by single ice advances, which change from sandy and drumlinized to silty and not drumlinized. In contrast to some published statements, drumlins are most commonly situated on carbonate bedrock rather than shale in this area of Paleozoic rocks. Drumlins occur both in areas of thick and thin drift with many examples sitting like barchan dunes on bare bedrock. Fluting tends to occur on silty or clayey tills. Clay tills such as Port Stanley, St Joseph, Rannoch, and Mornington, are never drumlinized. Referring to an area north-west of Toronto, White (1975) stated "The only drumlins in the report-area occur where the till consists of a relatively coarse material, i.e. where the matrix is sandy loam or loam. No drumlins were seen in the more than 200 square miles of the map-area underlain by the finer grained Halton Till (silt loam to loam) or Wildfield Till (clay to silty clay loam)."

\section{Nova Scotia}

Goldthwait (1924, p. 9r) stated that "One of the requirements for their [drumlins] growth is that the drift must contain a large amount of clay, which acts both as a lubricant, allowing the ice to slip over the drift, and as a cohesive agency, causing the clay to stick to the mound which is already started." In 
contrast, Gravenor (1974) reported drumlins near Yarmouth contained $20-33 \%$ gravel and the $<2 \mathrm{~mm}$ matrix contained $40-70 \%$ sand and $\mathrm{I}-5 \%$ clay. MacNeil (1965) also described many of the Nova Scotia drumlins as sandy.

\section{Canadian Shield}

Drumlins are widespread on the Canadian Shield and probably greatly outnumber the classic drumlins of south-eastern Canada and the north-eastern United States. Tills on the shield are notably coarse-textured (Scott, $\left[{ }^{\circ}\right.$ I976]).

\section{Boston area}

A classic drumlin area, as early as $189^{2}$ Crosby described the till, as determined by laboratory analyses, as low in clay and high in coarse constituents.

\section{New York}

Muller (1963) stated that "The present study affords no support to Fairchild's stress on clay content as a significant factor in till accretion. Chautauqua County drumlins are composed of till which is not notably clay-rich. Typical mechanical analyses show the till to be composed of subequal proportions of sand and silt, with the clay fraction ranging between 5 and $15 \%$. By coincidence, mapped areas of clay till are notably not drumlinized ....".

\section{Wisconsin}

After remarking that "Generally the drumlins of Wisconsin are composed of clayey to sandy clay till", Lasca (1970) went on to describe Jefferson County drumlins as consisting of "loam to sandy-loam till which commonly contains boulders". In a "late note" at the end of his paper he quoted analyses of the $<2 \mathrm{~mm}$ fraction as $72 \%$ sand and $11 \%$ clay. This certainly indicates the till is sandy.

\section{Discussion}

While the above few examples do not suffice to establish a general relationship, they are suggestive, and should act at least as a stimulus to further consideration of the texture of drumlinized till. Gravenor (1953) remarked that "most published analyses indicate that drumlins are sand-rich rather than clay-rich".

One wonders, in view of the numerous examples available of drumlins formed of sandy till, how the widespread preconception arose that drumlins are composed of clay till. Two factors occur to me. First, the use of the term "boulder clay", as equivalent to till, has undoubtedly brought clay into the picture quite by accident. The even less exact term "glacial clay" has had a similar effect. "Boulder clay" as a descriptive term indicates a mixture of boulders and clay. Some tills can be so described but most cannot be accurately described in this way. Descriptions of drumlins as composed of boulder clay should be read as not defining the grain-size distribution of the till. I would go further and recommend, as others have, that the use of the term "boulder clay" (and the equivalent French argile à blocaux) as equivalent to till be discontinued because they are so misleading.

Secondly, as suggested to me several years ago in the context of New England by a now-forgotten source, till in drumlins is fine-textured compared to the usual coarse material of the Appalachian region. In this regard I am reminded of a recent incident when a colleague, whose previous experience had been in the Cordilleran region of western Canada, first saw some Catfish Creek Till from Ontario he remarked on the fine texture of Ontario tills; Catfish Creek Till is in fact one of the coarsest tills in south-western Ontario.

Greater precision is required in describing till. Till is not just "till". Its texture must be described if useful relationships are to be derived. It is obvious from the literature that conceptions of what "clayrich" means vary considerably; sometimes anything that is not loose and gravelly is described as clayey.

The importance of standard size analyses cannot be over-emphasized (Karrow, [ $\left.{ }^{\circ} 1976\right]$ ). Standardized size-fraction boundaries are needed and proper descriptions of till, derived from these analyses, need to be applied to drumlins. Much inadequate and inaccurate description presently clutters up the literature, specifically on drumlins. As Smalley and Unwin (1968) have remarked "although much has been written about drumlins, very little hard fact has emerged". 


\section{TEXTURE AND THE ORIGIN OF DRUMLINS}

There has been much speculation on the origin of drumlins and a pre-occupation is evident with their shapes and grouping, occurrence of rock cores, and presence of stratified materials. Recently, there has been a shift in emphasis to consideration of soil mechanics principles. Smalley and Unwin (1968) proposed that dilatancy was an important factor and suggested an abundance of boulders might favour it. Menzies (1979[a]) suggested that relief of excess pore-water pressure is a critical factor in developing dilatancy, and implied that permeability could be important. He proposed that joints in underlying bedrock or permeable glacio-fluvial sediments could provide escape for the pore water. Coarse till would seem to provide higher permeability and easier drainage than fine till.

I endorse the recent trend to looking at the mechanics of materials for an explanation of drumlin formation. Surely this should include a more careful look at the texture of the material involved.

\section{Conclusions}

The texture of till in drumlins has commonly been given insufficient attention. Where till descriptions have been given, terms are often inadequately defined or inaccurately applied.

The till in drumlins should be subjected to laboratory analysis according to some stated standard procedure and the size parameters defined when statements on texture are made. When this has been practised widely, I believe it will be evident that drumlins form predominantly from sandy till. Perhaps if clay-till drumlins exist, the effect of the clayey matrix has been compensated by abundant boulders, a factor alluded to by Smalley and Unwin (1968).

Evidence is at least sufficient to show that general statements to the effect that drumlins are formed of clay-rich till are in error.

\section{MS. received 29 April 1980}

\section{REFERENCES}

Bloom, A. L. [ [ ${ }^{1}$ 1978.] Geomorphology: a systematic analysis of late Cenozoic landforms. Englewood Cliffs, N.J., Prentice-Hall.

Chapman, L. J., and Putnam, D. F. 1951. The physiography of southern Ontario. Toronto, University of Toronto Press for Ontario Research Foundation. Charlesworth, J. K. 1957 . The Quaternary era, with special reference to its glaciation. London, Edward Arnold.
2 vols.

Cowan, W. R. 1975. Quaternary geology of the Woodstock area. Ontario. Division of Mines. Geological Report 119.

Cowan, W. R. 1979. Quaternary geology of the Palmerston area. Ontario. Geological Survey. Report 187.

Crosby, W. O. 1892. Composition of the till or bowlder-clay [sic]. Proceedings of the Boston Society of Natural History, Vol. 25, p. II5-40.

Embleton, C., and King, C. A. M. 1968. Glacial and periglacial geomorphology. London, Edward Arnold.

Flint, R. F. [ ${ }^{\mathrm{C}} \mathrm{1}$ 947.] Glacial geology and the Pleistocene epoch. New York, John Wiley and Sons.

Flint, R. F. [ ${ }^{\mathrm{C}} \mathrm{r}$ 957.] Glacial and Pleistocene geology. New York, John Wiley and Sons.

Flint, R. F. [ $\left.{ }^{\mathrm{c}} \mathrm{1} 97 \mathrm{I}.\right]$ Glacial and Quaternary geology. New York, John Wiley and Sons.

Goldthwait, J. W. 1924. Physiography of Nova Scotia. Canada. Geological Survey. Memoir 140.

Gravenor, C. P. 1953. The origin of drumlins. American Journal of Science, Vol. 251, No. 9, p. 674-81.

Gravenor, C. P. 1974. The Yarmouth drumlin field, Nova Scotia, Canada. Journal of Glaciology, Vol. 13, No. 67, p. $45-54$.

Karrow, P.F. 1963 . Pleistocene geology of the Hamilton-Galt area. Ontario. Dept. of Mines. Geological Report 16.

Karrow, P. F. 1967 . Pleistocene geology of the Scarborough area. Ontario. Dept. of Mines. Geological Report 46.

Karrow, P. F. 1968. Pleistocene geology of the Guelph area. Ontario. Dept. of Mines. Geological Report 6r.

Karrow, P. F. 1970. Pleistocene geology of the Thornhill area. Ontario. Dept. of Mines. Industrial Mineral Report 32 .

Karrow, P. F. 1974. Till stratigraphy in parts of southwestern Ontario. Geological Society of America. Bulletin, Vol. 85 , No. 5 , p. $761-68$.

Karrow, P. F. [ ${ }^{\mathrm{C}} \mathrm{1} 976$.] The texture, mineralogy, and petrography of North American tills. (In Legget, R. F., ed. Glacial till. An interdisciplinary study. [Ottawa], Royal Society of Canada in co-operation with the National Research Council of Canada, p. 83-98. (Royal Society of Canada Special Publications, No. 12.))

Lasca, N. P. 1970. The drumlin field of southeastern Wisconsin. Wisconsin. Geological and Natural History Survey. Information Circular No. 15, p. E-1-E-13.

MacNeil, R. H. 1965. Variation in content of some drumlins and tills in southwestern Nova Scotia. Maritime Sediments, Vol. 1, No. 3, p. 16-19. 
Menzies, J. 1979[a]. The mechanics of drumlin formation with particular reference to the change in pore-water content of the till. Fournal of Glaciology, Vol. 22, No. 87, p. 373-84.

Menzies, J. ${ }_{1979}[\mathrm{~b}]$. A review of the literature on the formation and location of drumlins. Earth-Science Reviews, Vol. I4, No. 4, p. 315-59.

Muller, E. H. 1963. Geology of Chautauqua County, New York. Part II. Pleistocene geology. Bulletin of the New York State Museum and Science Service, No. $39^{2}$.

Scott, J. S. [ ${ }^{\mathrm{C}}{ }_{1976 .]}$ Geology of Canadian tills. (In Legget, R. F., ed. Glacial till. An interdisciplinary study. [Ottawa], Royal Society of Canada in co-operation with the National Research Council of Canada, p. 50-66. (Royal Society of Canada Special Publications, No. 12.))

Sharpe, D. R. 1979. Quaternary geology of the Merrickville area. Ontario. Geological Survey. Report I80.

Smalley, I. J., and Unwin, D. J. 1968. The formation and shape of drumlins and their distribution and orientation in drumlin fields. Fournal of Glaciology, Vol. 7, No. 51, p. 377-9o.

Watt, A. K. 1957. Pleistocene geology and ground-water resources of the township of North York, York County. Ontario. Dept. of Mines. Annual Report, Vol. 64, Pt. 7, 1955.

White, O. L. 1975. Quaternary geology of the Bolton area. Ontario. Division of Mines. Geological Report I 17. 